\title{
Molecular Characterization of Tirupati Isolate of Pigeonpea Sterility Mosaic Virus
}

\author{
K. Sailaja ${ }^{1^{*}}$, B.V. Bhaskara Reddy ${ }^{2}$, L. Prasanthi ${ }^{2}$ and P. Sarada Jayalakshmi Devi ${ }^{3}$ \\ ${ }^{1}$ Department of Plant Pathology, S. V. Agricultural College, Tirupati, Acharya N. G. Ranga \\ Agricultural University, Andhra Pradesh, India \\ ${ }^{2}$ Institute of Frontier Technology, Regional Agricultural Research Station, Tirupati, Acharya N. \\ G. Ranga Agricultural University, Andhra Pradesh, India \\ ${ }^{3}$ Acharya N. G. Ranga Agricultural University, Guntur, Andhra Pradesh, India \\ *Corresponding author
}

\section{A B S T R A C T}

Keywords

PPSMV, EMARaV, FMV, SMD.

Article Info

Accepted:

17 September 2017

Available Online:

10 November 2017
Nucleotide sequence analysis of partial replicase gene of Pigeonpea sterility mosaic virus-Tirupati isolate shown $96.9 \%$ similarity with ICRISAT-PPSMV-I followed by PPSMV-I-Chevella (81.2\%), PPSMV-IIICRISAT $(55.3 \%)$ and $<51 \%$ with other Emaraviruses. Based on 322bp partial replicase sequence homology studies, the present isolate is closely related to PPSMV-I causing SMD at ICRISAT. PPSMV- TPT - isolate formed unique clade with ICRISAT-PPSMV-I isolate within cluster that consists of PPSMV I-Chevella isolate in phylogenetic tree constructed based on partial replicase gene sequences of PPSMV-I, PPSMV-II and other Emaravirus sequences downloaded from GenBank.

\section{Introduction}

Pigeonpea [Cajanus cajan (L.) Millsp.], which is also referred as red gram or arhar, is a perennial shrub, with its centre of origin in India. In India pigeonpea is cultivated in 3.9 $\mathrm{m}$. ha area with 3.1 metric tonnes of production. In Andhra Pradesh it is cultivated in $0.45 \mathrm{~m}$. ha area with 0.24 metric tonnes of production (www.indiastat.com, 2013-14). Its cultivation is increasing in semi-arid areas because of the crop's ability to thrive under prolonged drought and in degraded lands (Upadhyaya et al., 2012). Because of its diverse usages as a food, fodder and fuel it plays an important role in food security, balanced diet and alleviation of poverty (Rao et al., 2002). Although, India leads the world both in area and production of pigeonpea but its productivity is lower than the world average. This is attributed to factors such as various biotic (e.g. diseases like Fusarium wilt, sterility mosaic and pod borers) and abiotic (e.g. drought, salinity and water logging) stresses.

More than 210 pathogens, 15 viruses, 3 virus like diseases and one viroid has been reported 
to naturally infect pigeonpea (Nene et al., 1996). Out of all, Sterility mosaic disease (SMD) caused by Pigeonpea sterility mosaic virus (PPSMV) a mite transmitted single stranded multipartite RNA virus belonging to Emaravirus genus is the economically most important viral disease in India, causing an estimated annual loss of more than US\$300 million (Reddy et al., 1998). SMD was first reported from Pusa (Bihar) in 1931 (Mitra, 1931) and is mostly endemic to India, Nepal, Bangladesh and Myanmar. The disease has also been reported from Thailand (Nene et al., 1996) and Sri Lanka (Newton and Peiris, 1953). SMD is also one of the major constraints in pigeonpea production in ricebased cropping systems in Myanmar (Han et al., 2001). A total of five different SMD isolates has been reported and of these, three SMD isolates namely Patancheru, Bangalore and Coimbatore has been characterized by differential host response. Hence the present investigation was under taken to identify which isolate of PPSMV is present at Tirupati and to characterize it.

\section{Materials and Methods}

Total RNA was isolated from young Pigeonpea sterility mosaic virus infected leaves by triazol method (sigma). The extracted RNA was checked for quality and integrity by denatured agarose gel electrophoresis. From the extracted RNA, cDNA was synthesized and amplified by PCR using specific primers and product was eluted from agarose gel and cloned into pTZ57R/T vector and transformed into $E$. coli cells (Top 10) following standard protocols (Sambrook et al., (2001). The recombinant clones containing partial replicase gene were identified by colony PCR and restriction digestion with BamHI and Xba 1 (Fig. 3). The partial replicase sequence was aligned with Emaravirus sequences available in database by Bioedit programme (Fig. 5).

\section{Results and Discussion}

Two sharp bands of 28S and 18S RNA were observed in denatured agarose electrophoresis indicating that the quality of RNA is good (Fig. 1). The extracted RNA was subjected to RT-PCR which yielded 322 bp product (Fig. 2 ). Comparison of nucleotide sequence of partial replicase gene of Pigeonpea sterility mosaic virus from Tirupati with other Emaravirus sequences available in the GenBank (Table 1) shows that PPSMV-TPTisolate share $96.9 \%$ similarity with ICRISAT-PPSMV-I followed by PPSMV-IChevella (81.2\%), PPSMV-II-ICRISAT $(55.3 \%)$ and $<51 \%$ with other Emaraviruses (Table 2). Based on 322bp partial replicase sequence homology studies, the present isolate is closely related to PPSMV-I causing SMD at ICRISAT. Since the sequencing information of Coimbatore and Bangalore isolates were not available to compare the sequence and to identify the isolate present at Tirupati, it was concluded that the present isolates is more closely related to ICRISAT isolate. Moreover the $322 \mathrm{bp}$ partial sequence information is not enough to classify or identify strains; hence it is necessary to clone and sequence full length sequence of replicase and coat protein genes. All our efforts to amplify PPSMV-II with available primers failed due to low concentration of virus in the plants or absence of PPSMV-II with SMD at Tirupati.

Phylogenetic tree was constructed based on partial replicase gene sequences of PPSMV-I, PPSMV-II and other Emaravirus sequences downloaded from GenBank formed three major clusters. PPSMV - TPT - isolate formed unique clade with ICRISAT-PPSMV-I isolate within cluster that consists of PPSMV IChevella isolate. The ICRISAT - PPSMV II and PPSMV-II - Chevella isolates formed another clade within second cluster which consist of FMV and EMARaV. The third 
cluster consist of RLBV, RRV, and RYRSaV which shows $<30 \%$ sequence homology with PPSMVI-TPT isolate (Fig. 4). From the above results it is clear that PPSMV -TPT isolate has more similarity with ICRISATPPSMV-I isolate than PPSMV II.

Table.1 List of Emaraviruses and their accession numbers used for sequence comparison

\begin{tabular}{|c|l|l|}
\hline S. No & \multicolumn{1}{|c|}{ Name of the Emaravirus } & \multicolumn{1}{|c|}{$\begin{array}{c}\text { GenBank Accession } \\
\text { Number }\end{array}$} \\
\hline 1 & Pigeonpea sterility mosaic virus 1 ICRISAT-PPSMV-1 & HF568801 \\
\hline 2 & $\begin{array}{l}\text { Pigeonpea sterility mosaic virus 1- PPSMV - I- } \\
\text { Chevella }\end{array}$ & LN887951 \\
\hline 3 & $\begin{array}{l}\text { Pigeonpea sterility mosaic virus 2 (PPSMV-II)- } \\
\text { ICRISAT }\end{array}$ & HF912243 \\
\hline 4 & PPSMV - II-Chevella & LN651310 \\
\hline 5 & $\begin{array}{l}\text { European mountain ash ringspot - associated virus } \\
\text { (EMARaV). }\end{array}$ & AY563040 \\
\hline 6 & Fig mosaic virus (FMV). & AM941711 \\
\hline 7 & Rose rosette virus (RRV). & NC-015298 \\
\hline 8 & Raspberry leaf blotch virus (RLBV). & FR823299 \\
\hline 9 & Redbud yellow ringspot-associated virus (RYRSaV). & JF795479 \\
\hline
\end{tabular}

Table.2 Sequence identity matrix of partial replicase gene of Pigeonpea sterility mosaic virus infecting pigeonpea at Tirupati with other Emaraviruses

\begin{tabular}{|c|c|c|c|c|c|c|c|c|c|c|c|}
\hline Virus & 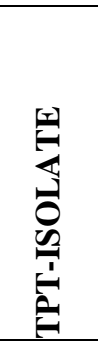 & 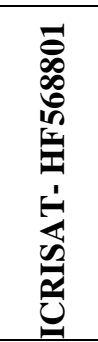 & 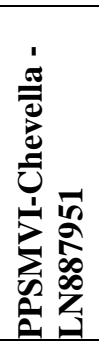 & 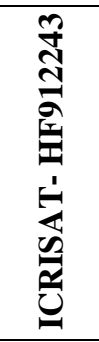 & 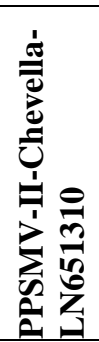 & 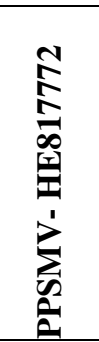 & 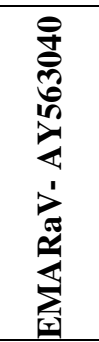 & 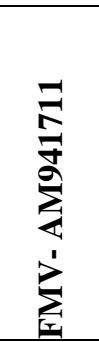 & 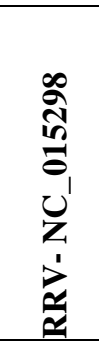 & 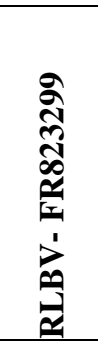 & 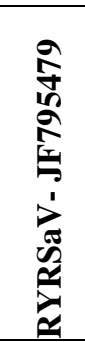 \\
\hline TPT-ISOLATE & ID & 0.969 & 0.812 & 0.544 & 0.553 & 0.255 & 0.457 & 0.513 & 0.342 & 0.347 & 0.339 \\
\hline ICRISAT- HF568801 & 0.969 & ID & 0.840 & 0.556 & 0.565 & 0.261 & 0.472 & 0.510 & 0.336 & 0.350 & 0.348 \\
\hline $\begin{array}{l}\text { PPSMVI-Chevella- } \\
\text { LN887951 }\end{array}$ & 0.812 & 0.840 & ID & 0.486 & 0.495 & 0.279 & 0.469 & 0.483 & 0.342 & 0.341 & 0.330 \\
\hline ICRISAT- HF912243 & 0.544 & 0.556 & 0.486 & ID & 0.978 & 0.300 & 0.570 & 0.625 & 0.324 & 0.320 & 0.342 \\
\hline $\begin{array}{l}\text { PPSMV-II-Chevella- } \\
\text { LN651310 }\end{array}$ & 0.553 & 0.565 & 0.495 & 0.978 & ID & 0.300 & 0.561 & 0.619 & 0.321 & 0.317 & 0.336 \\
\hline PPSMV- HE817772 & 0.255 & 0.261 & 0.279 & 0.300 & 0.300 & ID & 0.255 & 0.282 & 0.297 & 0.271 & 0.260 \\
\hline EMARaV-AY563040 & 0.457 & 0.472 & 0.469 & 0.570 & 0.561 & 0.255 & ID & 0.524 & 0.311 & 0.358 & 0.348 \\
\hline FMV- AM941711 & 0.513 & 0.510 & 0.483 & 0.625 & 0.619 & 0.282 & 0.524 & ID & 0.299 & 0.298 & 0.299 \\
\hline RRV- NC_015298 & 0.342 & 0.336 & 0.342 & 0.324 & 0.321 & 0.297 & 0.311 & 0.299 & ID & 0.425 & 0.495 \\
\hline RLBV- FR823299 & 0.347 & 0.350 & 0.341 & 0.320 & 0.317 & 0.271 & 0.358 & 0.298 & 0.425 & ID & 0.358 \\
\hline RYRSaV- JF795479 & 0.339 & 0.348 & 0.330 & 0.342 & 0.336 & 0.260 & 0.348 & 0.299 & 0.495 & 0.358 & ID \\
\hline
\end{tabular}


Fig.1 Aagarose gel electrophoresis of total RNA in TBE buffer containing guanidine isothiocynate

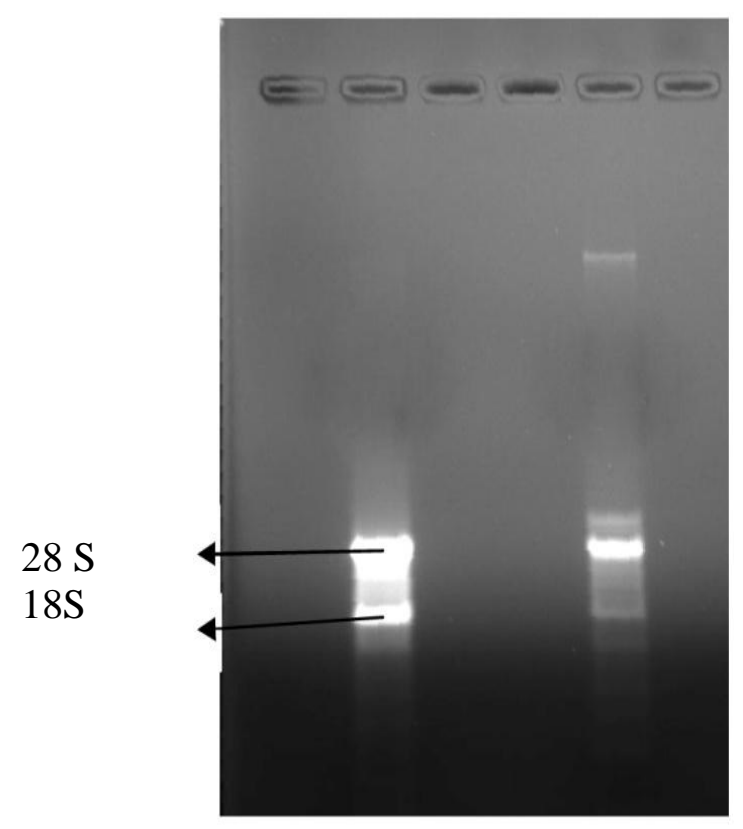

Fig.2 Amplification of total RNA from SMD infected plants with partial replicase gene primers

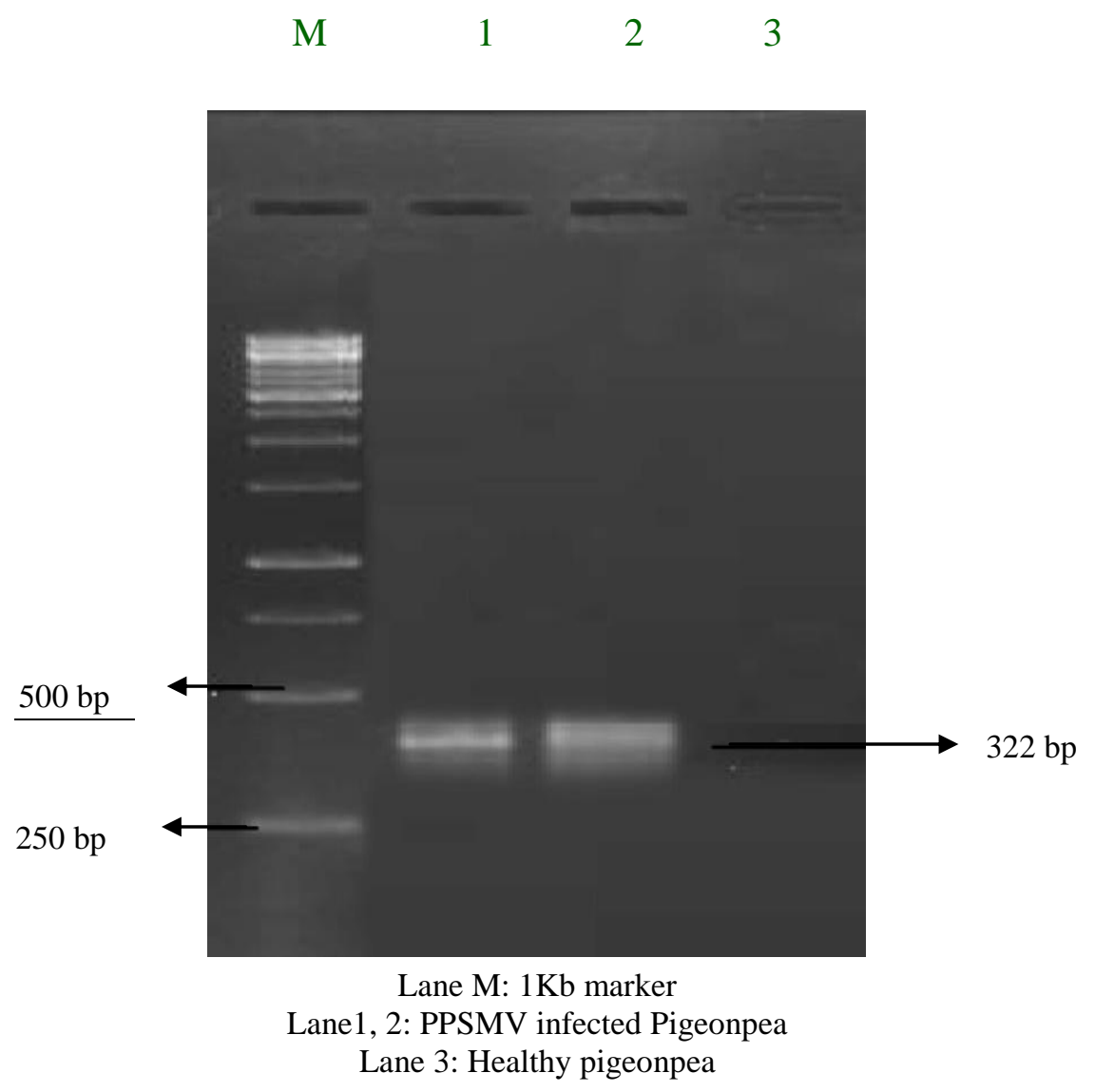


Fig.3 Confirmation of PPSMV replicase gene clones by restriction digestion and by colony PCR

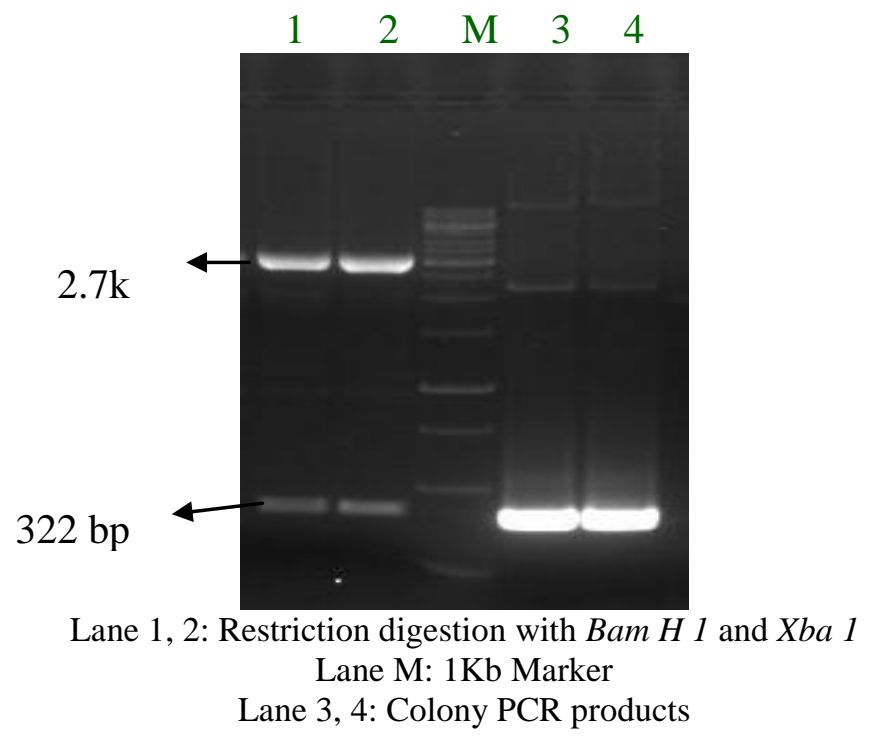

Fig.4 Phylogenetic tree of the replicase gene sequence of Pigeonpea sterility mosaic virus with other Emaravirus sequences. Abbreviations and GenBank accession numbers of Emaravirus used were given in table 1

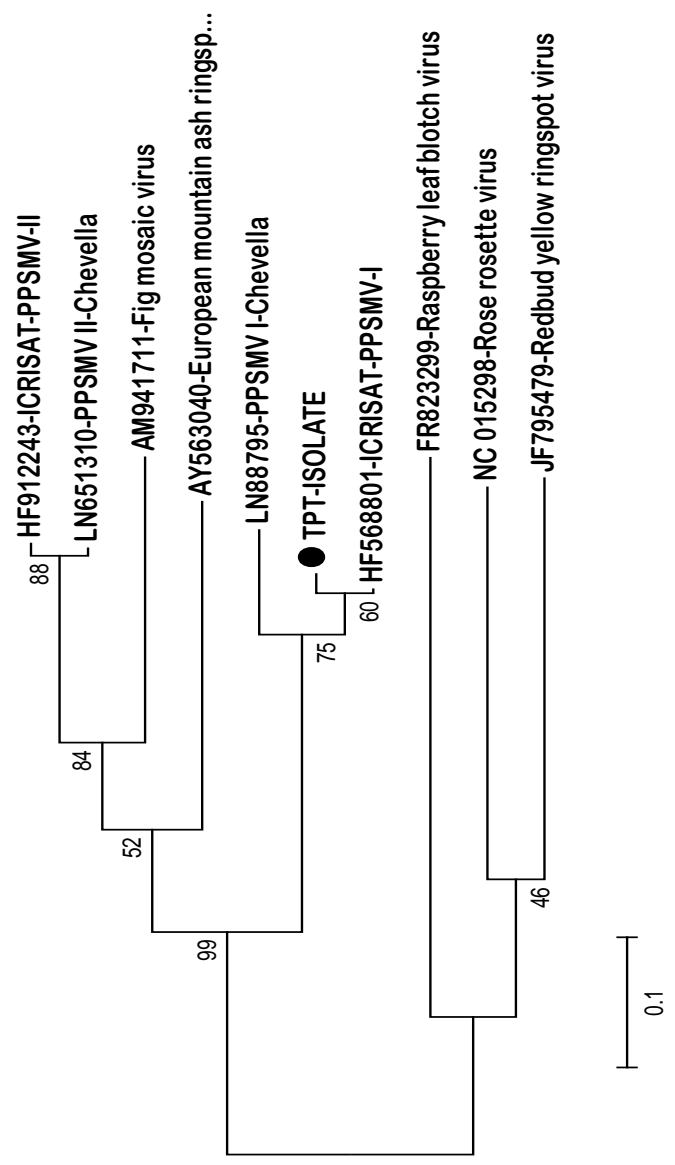


Fig.5 Alignment of replicase gene sequence of Pigeonpea sterility mosaic virus with other Emaraviruses from database.
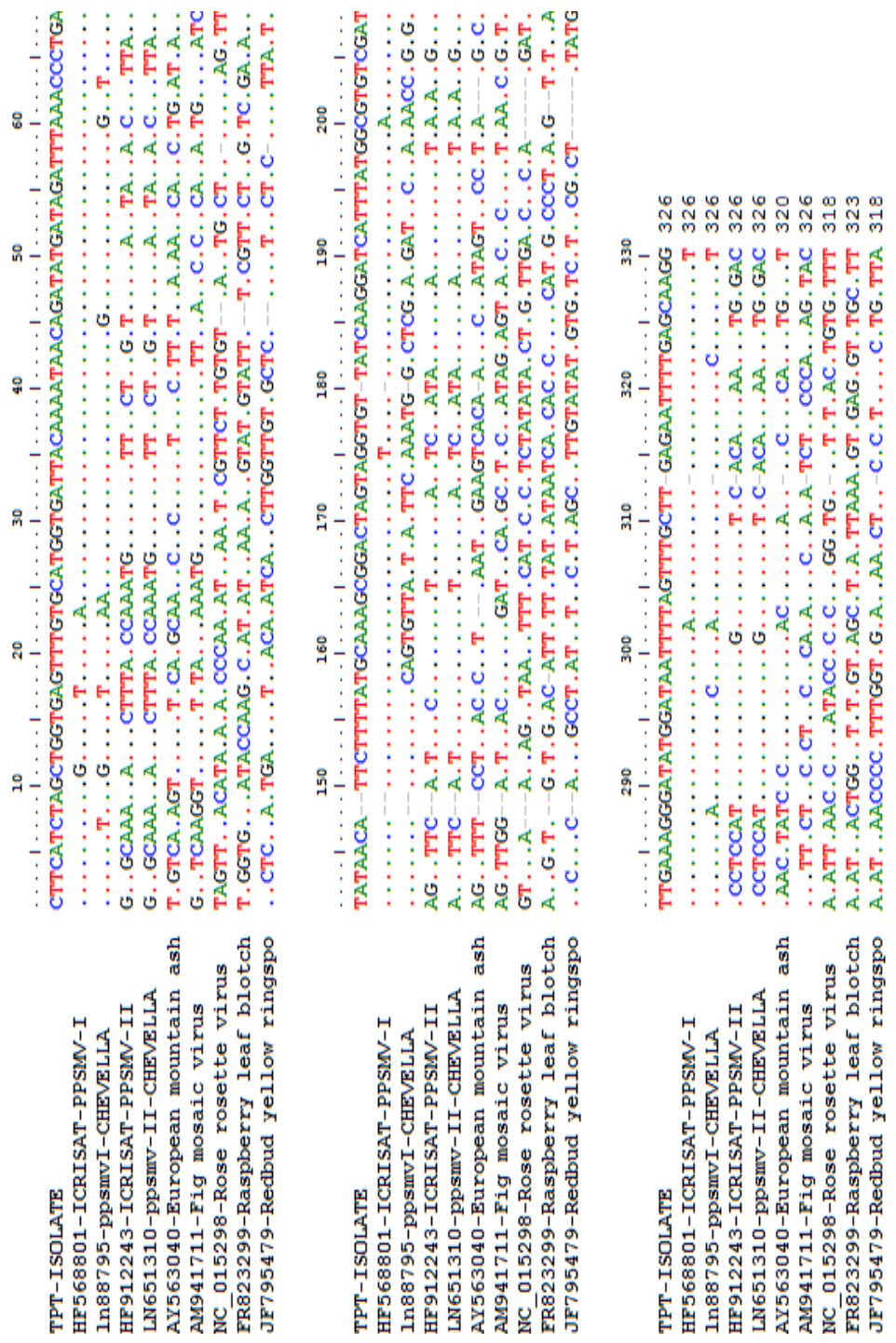

Emaravirus is a recently established viral genus that is unassigned to any family of plant viruses that includes segmented negative ssRNA viruses with enveloped spherical particles, approximately $200 \mathrm{~nm}$ dia. The European mountain ash ringspot associated virus (EMARaV) is the type species of this genus and has genome composed of four RNA segments. The others two approved members of Emaraviruses are Fig mosaic virus (FMV), Rose rosette virus (RRV), High plain virus (HPV), Pigeonpea sterility mosaic virus (PPSMV), Raspberry leaf blotch virus (RLBV)
(Ehret and Muhlbach, 2012). Degenerate oligonucleotide primers were developed to the conserved amino acid sequences in the RNA dependent RNA polymerase gene (RdRp) which shown amplification in RT-PCR assay and allowed the identification of Pigeonpea sterility mosaic virus and Maize red stripe virus (MRSV) (Elbeaino et al., 2013). PPSMV and MRSV are close to RRV and RLBV respectively and belong to two separate clades in the phylogenetic tree constructed with 92 amino acid polypeptide putatively encoded by RNA1 (Elbeaino et al., 2013). Complete 
sequencing of PPSMV associated with SMD was achieved by deep sequencing and results revealed that it has 5 RNA segments. The most conserved RNA1 segment has a level of nucleotide identity from 48 to $70 \%$ with emaraviruses. The nucleotide identity in other RNA segment was lower, with values from 38 to $59 \%$ for RNA2 and 30 to $57 \%$ for RNA3, 4, 5 and 6 showed no homology to any viral proteins present in GenBank (Elbeaino et al., 2014). A new novel virus associated with pigeonpea was discovered in India which differs from earlier reported PPSMV with respect to sequence homology of RNA 1, RNA 2, RNA 3 segments. It has highest homology with Fig mosaic virus and share $48 \%$ (RNA3) to $62.5 \%$ (RNA 1) sequence identity with PPSMV. Based on molecular, biological and epidemiological features, this novel virus is the second Emaravirus infecting pigeonpea for which they named it as PPSMV2. This new viral entity showed consistent grouping with FMV and RRV which formed a cluster of their own, clearly distinct from PPSMV 1 (Elbeaino et al., 2015).

\section{References}

Elbeaino, T., Digiaro, M., Uppala, $M$ and Sudini, H. 2014. Deep sequencing of Pigeonpea sterility mosaic virus discloses five RNA segments related to emaraviruses. Virus Research. 188: 27-31.

Elbeaino, T., Digiaro, M., Uppala, M and Sudini, H. 2015. Deep sequencing of dsRNAs recovered from mosaic-diseased pigeonpea reveals the presence of a novel Emaravirus: Pigeonpea sterility mosaic virus 2. Archives of Virology. 160(8): 2019-2029.

Elbeaino, T., Whitfield, A., Sharma, $M$ and Digiaro, M. 2013. Emaravirus - specific degenerate PCR primers allowed the identification of partial RNA-dependent
RNA polymerase sequences of Maize red stripe virus and Pigeonpea sterility mosaic virus. Journal of Virological Methods. 188(1-2): 37-40.

Han, T., Win, M.K., Shwe, A., Soe, T., Aye, T., Nyi, N., Thet, K.K and Ramakrishna, A. 2001. Legumes in rice-based cropping systems in Myanmar: constraints and opportunities. Legumes in rice-based cropping systems in tropical Asia: constraints and opportunities. 42-61.

Mitra, M. 1931. Report of Imperial Mycologist. Scientific Reports of the Imperial Institute of Agricultural Research, Pusa. 30: 45-71.

Nene, Y.L., Sheila, V.K and Sharma, S.B. 1996. A world list of Chichpea and Pigeonpea pathogens. 5 th Edition. ICRISAT publication. 25.

Newton, W and Peiris, T.W.L. 1953. Virus diseases of plants in Cylon. F. A. O. Plant Protection Bulletin. 2: 17-21.

Rao, S.C., Coleman, S.W and Mayeux, H.S. 2002. Forage production and nutritive value of selected pigeonpea ecotypes in the Southern Great Plains. Crop Science. 42(4): 12591263

Reddy, M. V., Raju, T. N and Lenne, J. M. 1998. Diseases of pigeonpea. The Pathology of Food and Pasture Legumes. Wallingford, Oxfordshire: C. A. B. International. 517558.

Sambrook, J and Russel, D.W. 2001. Molecular Cloning - a Laboratory Manual. Third edition. New York, NY: Cold Spring Harbor Laboratory Press.

Upadhyaya, H.D., Kashiwagi, J., Varshney, R.K., Gaur, P.M., Saxena, K., Krishnamurthy, L., Gowda, C.L.L., Pundir, R.P.S., Chaturvedi, S.K., Basu, P.S and Singh, I.P. 2012. Phenotyping chickpeas and pigeonpeas for adaptation to drought. Frontiers in Plant Physiology. 3(179): 1-10.

\section{How to cite this article:}

Sailaja, K., B.V. Bhaskara Reddy, L. Prasanthi and Sarada Jayalakshmi Devi, P. 2017. Molecular Characterization of Tirupati Isolate of Pigeonpea Sterility Mosaic Virus. Int.J.Curr.Microbiol.App.Sci. 6(11): 2212-2218. doi: https://doi.org/10.20546/ijcmas.2017.611.262 